\title{
Філіnп БЮТІЕН
}

Вставка 3

\section{«WAHRNEHMUNG»: ЛЕКСИЧНІ ІГРИ ГЕГЕЛЯ}

\author{
VERITÉ
}

Початок «Феноменології духа» дезорієнтує читача, звиклого до Ляйбніцевих і Кантових розрізнень, оскільки просто ігнорує термінологічну пару Empfindung/ Wahrnehmung, тобто - саме співіснування відчуття та сприйняття у пізнавальному акті. Те, що передує Wahrnehmung, у Гегеля має назву sinnliche Gewissheit [чуттєва достовірність, фр. certitude sensible]. Тоді виникає запитання не про стосунок відчуття до сприйняття (як сходження до принципу), складеного (різноманітне у відчутті) до простого (зв'язок різноманітних змістів у свідомості, а згодом - у єдності Я), а про двоетапний процес, що приводить у дію різноманітні модальності схоплення істинного всередині свідомості. Кожен із двох етапів породжує свою власну фігуру істини, «своє істинне» (trad. fr. J.-P. Lefebvre, p. 114; у випадку сприйняття йдеться про річ), але спільним для них обох є прагнення вловити (prise) чи полонити істинне. Таким чином, перше речення розділу про «Сприйняття», що водночас $є$ й підсумком міркувань про чуттєву достовірність, повинне бути прочитане як гра довкола дієслова nehmen, себто «схоплювати, вловлювати»:

Die unmittelbare Gewissheit nimmt sich nicht das Wahre, denn ihre Wahrheit ist das Allgemeine; sie aber will das Diese nehmen. Die Wahrnehmung nimmt hingegen das, was ihr das Seiende ist, als Allgemeines.

Безпосередня достовірність не сприймає істинного, бо ії істиною є універсальне; вона ж воліє сприйняти Ось-Це. Сприйняттяя ж, навпаки, те, що для нього є сущим, схоплює як щось універсальне.

Hegel, Die Phänomenologie des Geistes, A.II, in Werke, Band 3, Frankfurt a. M. 1979, S. 93.

La certitude immediate ne se saisit pas du vrai, car sa verite est l'universel; alors qu'elle veut prendre le Ceci. La perception, a l'inverse, prend comme quelque chose d'universel ce qu'elle considere comme ce qui est.

Безпосередня достовірність не схоплює істинного, бо їі істиною $є$ універсальне; вона ж воліє вловити $O c b-Ц е$. Перцепція ж, навпаки, вловлює як щось загальне те, що вона розглядає як те, що $\epsilon$.

Hegel, La Phénoménologie de l'esprit, trad. fr. J.-P. Lefebvre, p. 103; [курсив мій - М.Ф.]

Чуттєва достовірність спрямована на одиничність, на «ось-це», але її власна діалектика відкриває, що та шукана одиничність є загальним, адже у «тут» 
завжди є «сукупність інших тут»; сприйняття, навпаки, одразу вловлює річ як загальне і є відповідником доброго глузду (bon sense), для якого світ - це світ речей (trad. fr. J.-P. Lefebvre, p. 114). Усі французькі перекладачі в цьому місці вдавалися до наполегливого повторення дієслова prendre «уловлювати» (пор. фр. пер. Ж. Іпполіта - La Phénoménologie de l'esprit, trad. fr. J. Hyppolite, p. 93, який навіть робить на цьому наголос, відтворюючи початкове nimmt sich як prendre possession «заволодівати»). Проте це нім. дієслово може мати різні вжитки, що позначають у Гегеля поступ від чуттєвої достовірності до сприйняття. Коли Gewissheit [достовірність] прагне вловити, впіймати без жодного опосередкування, то Wahrnehmung - це «вловлення як...» (nimmt... als), точніше кажучи, «вловлення-як-істинного» (Wahr-nehmen). Отже, Wahrnehmung явно передбачає певну активність або рефлексію свідомості; й оскільки перцепція є певним «уловленням-як...», свідомість, що здійснює перцепцію, відкриває також і можливість ілюзії (Täuschung) як особливої форми не-істини, яку ця свідомість винаходить і протиставляє істині речі. Втім, прагнучи схопити річ у їі істині, свідомість губиться в діалектиці речі та її властивостей (Eigenschaften), Одного й загального, вловлення й рефлексії, у всьому тому, що Гегель називає Sophisterei «софістика» перцепції і що знаходить тимчасове розв'язання у «царстві здатності розуміти» (das Reich des Verstandes, фp. royaume de l'entendement; trad. fr. J.-P. Lefebvre, p. 113).

Французький перекладач стикається з ускладненням лексичного штибу: він не може відтворити гру слів, застосовану Гегелем при розкладанні дієслова wahrnehmen на складники. Щоб відтворити інверсію sein Nehmen des Wahren стосовно свідомості, Ж.-П. Лефевр пропонує, мабуть, найточніший відповідник: sa captation du vrai (здійснюване ним «захоплення іншого»; ibid., p. 110), адже captation вказує на лат. capere, присутнє у percipere ${ }^{\mathrm{i}}$ (Ж. Іполіт переклав цей вираз як sa préhension du vrai його похоплення істинного - trad. fr. J. Hyppolite, p. 102); але ж ці французькі іменники, la captation i le vrai, не утворять єдиного дієслова, як іхні німецькі відповідники (das Nehmen і des Wahren, якщо переставити їх місцями, утворюють дієслово wahrnehmen). Перцепція у французькій мові не обов'язково означатиме те «істино-захоплення», яке Гегель дає почути у wahr-nehmen.

Втім, Гегелева гра 3 дієсловом wahrnehmen загалом є перекладною, як свідчить перший процитований уривок. Натомість конче потребує пояснення внутрішня зв'язність тієї траєкторії, що веде від Ляйбніца до Гегеля. Історія теорій перцепції у Німеччині $є$ історією франко-німецькою, що добре засвідчує неологізм aperception, французький термін, створений німцем Ляйбніцем й акліматизований у мові Канта. Ініціатива Гегеля, що вперше вирішив дати почути етимологію Wahrnehmung, є безпосередньою відповіддю цій традиції. Вона відповідає стратегії вилучення з цього слова будь-якого сліду його почасти франкомовного минулого, здійснюваної тієї самої миті, коли Гегель протиставляє аналізові різноманітних інстанцій чи органів пізнання парадигму істини та достовірності. У цьому сенсі заміна старої термінологічної пари Empfindung/Wahrnehmung новою Gewissheit/Wahrnehmung постає як добра ілюстрація мовних і мисленнєвих методів, до яких вдався Гегель, щоб здійснити перехід від теорії пізнання (див. ЕПІСТЕМОЛОГІя) до вчення про знання. 


\section{БІБЛІОГРАФІЯ}

HEGEL Georg Wilhelm Friedrich, Die Phänomenologie des Geistes, in Sämtliche Werke. Kritische Ausgabe, Hrsg. G. Lasson und J. Hoffmeister, Hamburg Meiner, 1937; La Phénoménologie de l'esprit, trad. fr. J. Hyppolite, Aubier 1941; Phénoménologie de l'esprit, trad. fr. J.-P. Lefebvre, Aubier, 1991.

\section{ПРИМІТКА ПЕРЕКЛАДАЧА}

і «Приймати в себе, охоплювати, опановувати, захоплювати, отримувати, сприймати» (лат.). Percipio утворене із двох складників: префікса per- (позначає в цьому разі дію, яка відбувається через посередництво чогось) та дієслова cipio (=capio, 1-ша особа однини від capere «брати, отримувати, ловити, полонити, приймати, засвоювати, поглинати, вміщувати, терпіти, досягати, осягати»).

Philippe Büttgen, Professor of the philosophy of religion, University Paris I Pantheon-Sorbonne.

Філіпп Бютген, професор філософії релігї̈ університету Париж I Пантеон-Сорбона.

Филипп Бюттген, профессор философии релагии университета Париж I Пантеон-Сорбонна. 